\title{
POTENTIAL DRIFT AND INJURY OF HERBICIDES SPRAYED IN A WIND TUNNEL
}

\author{
Guilherme M. P. de Oliveira ${ }^{*}$, Marco A. Gandolfo², Rone B. de Oliveira², Stella M. P. de Oliveira ${ }^{3}$, \\ Vinicius A. Martins ${ }^{2}$
}

${ }^{1 *}$ Corresponding author. State University of Londrina/ Londrina - PR, Brazil. E-mail: guilhermemendespio@gmail.com ORCID ID: https://orcid.org/0000-0001-6752-3963

\section{KEYWORDS}

dicamba, glyphosate, herbicide mixture, application technology, 2,4-D.

\begin{abstract}
The possibility of synthetic auxin applications in crops increases the risk of injury to sensitive plants. The aim of this study was to quantify the drift of herbicides sprayed in a wind tunnel and the injury in cotton plants. The experimental design was a completely randomized design with five treatments and four replications. The tested spray solutions were dicamba $\left(0.250 \mathrm{~L} \mathrm{c.p.} \mathrm{ha}{ }^{-1}\right)$, glyphosate $\left(0.625 \mathrm{~L} \mathrm{c.p.} \mathrm{ha}{ }^{-1}\right), 2,4-\mathrm{D}\left(0.250 \mathrm{~L} \mathrm{c.p.} \mathrm{ha}{ }^{-1}\right)$, glyphosate $+2,4-\mathrm{D}\left(0.625\right.$ L c.p. ha ${ }^{-1}+0.250$ L c.p. ha $\left.{ }^{-1}\right)$, and glyphosate + dicamba $\left(0.625 \mathrm{~L}\right.$ c.p. $\mathrm{ha}^{-1}+0.250 \mathrm{~L}$ c.p. $\left.\mathrm{ha}^{-1}\right)$. Drift was quantified in a wind tunnel, collected at distances of 5, 10, and $15 \mathrm{~m}$ in relation to the spray tip. Cotton plants were placed in the same wind tunnel and the injury was visually evaluated for at 3, 7, and 15 days after application (DAA). The addition of glyphosate to dicamba and 2,4-D potentiated the drift from $5 \mathrm{~m}$. At 10 and $15 \mathrm{~m}$, dicamba and 2,4-D in isolation had the lowest drift potential. At $5 \mathrm{~m}$, the injury is higher than at other distances regardless of the spray solution. At 10 $\mathrm{m}, 2,4-\mathrm{D}$ in isolation presented the highest injury when compared to dicamba in isolation at 7 and $15 \mathrm{DAA}$. At 10 and $15 \mathrm{~m}$, the addition of glyphosate to dicamba enhances the injury in cotton plants and herbicide mixtures do not differ from each other in relation to injury.
\end{abstract}

\section{INTRODUCTION}

The application of herbicides is the main method of controlling weeds in agricultural areas and, consequently, contributes to the reduction of productivity losses (Heap, 2014; Godinho Júnior et al., 2017). The herbicides 2,4-D and glyphosate are among the most used in pre-sowing applications for desiccation and post-sowing due to their cost-benefit relationship (Gandolfo et al., 2012) and efficiency in controlling eudicotyledon weeds (Minozzi et al., 2014; Schaianne et al., 2017).

With expectations of improving the control of resistant and tolerant weeds to glyphosate, the herbicide dicamba has been studied for commercial use in Brazil. As the 2,4-D, this herbicide belongs to the group of synthetic auxin (Grossmann et al., 1996), used in the control of eudicotyledons (Silva et al., 2007). Dicamba had the trade liberalization deferred (CTNBio, 2016), thus allowing the producers to use these new resources (Mohseni-Moghadam \& Doohan, 2015).

In regions where cotton cultivars tolerant to synthetic auxins were adopted, the use of herbicides such as dicamba and 2,4-D will increase (Mortensen et al., 2012). This shows the need for care in the application of these herbicides (Godinho Júnior et al., 2017) in areas close to sensitive crops (Gandolfo et al., 2012).

Cotton crop is highly sensitive to the herbicides 2,4D and dicamba (Oliveira et al., 2015), which may represent a risk to its development and productivity (Egan et al., 2014), a fact observed by Johnson et al. (2012) and Smith et al. (2017) when simulating the drift of these herbicides.

The controlled meteorological conditions found in wind tunnels make them adequate for drift studies (Sidahmed et al., 2004). There is a need for herbicide research to be performed considering the products and their mixtures, allowing the weed control to be carried out with the highest possible environmental safety, avoiding the occurrence of drift and damage caused by it in adjacent areas.

It is assumed that the herbicide affects the drift level and thus, this study aimed to quantify the drift of herbicides sprayed in a wind tunnel and the injury in cotton plants.

\section{MATERIAL AND METHODS}

The experiments were carried out between April and June 2017 at the Nucleus of Research in Application Technology of Agrochemicals and Agricultural Machinery

\footnotetext{
${ }^{2}$ State University of Northern Paraná/ Bandeirantes - PR, Brazil.

${ }^{3}$ Goiano Federal Institute/ Rio Verde - GO, Brazil.

Received in: 4-23-2018

Accepted in: 10-25-2018
} 
(NITEC) of the State University of Northern Paraná, campus of Luiz Meneghel, Bandeirantes, PR, Brazil.

Experiment I - Potential drift of herbicides sprayed in a wind tunnel

The flat spray nozzle with pre-orifice model ADI 11002 aiming at the formation of middle-class droplets. The working pressure was $414 \mathrm{kPa}$, with a flow rate corresponding to $0.91 \mathrm{~L} \mathrm{~min}^{-1}$.

Spray solution concentration was determined by adding herbicides in gallons and completing them up to 25
L of water, aiming at the application volume of $100 \mathrm{~L} \mathrm{ha}^{-1}$. A marker Brilliant Blue dye FCF $11.00 \%$ was added at a concentration of $6 \mathrm{~g} \mathrm{~L}^{-1}$ in order to estimate the amount deposited.

The experimental design was a completely randomized design with five treatments and four replications (Table 1). The experiment was performed in a $20 \mathrm{~m}$ long wind tunnel with a $2 \mathrm{~m}$ square cross-section, with a $0.9 \mathrm{~m}$ diameter double-helix axial fan driven by the power take-off (PTO) of a tractor (Gandolfo et al., 2013).

TABLE 1. Description of the samples used for the experiment. Bandeirantes, PR, Brazil.

\begin{tabular}{ccc}
\hline Treatment & Concentration & Dose \\
\hline Dicamba & $480 \mathrm{~g} \mathrm{a.e.} \mathrm{L}$ & $0.25 \mathrm{~L} \mathrm{ha}^{-1}$ \\
Glyphosate & $480 \mathrm{~g} \mathrm{a.i.} \mathrm{L}$ & $0.625 \mathrm{~L} \mathrm{ha}^{-1}$ \\
2,4-D** & $806 \mathrm{~g}$ a.i. L $\mathrm{L}^{-1}$ & $0.25 \mathrm{~L} \mathrm{ha}^{-1}$ \\
Glyphosate + 2,4-D & & $0.625 \mathrm{~L} \mathrm{ha}^{-1}+0.25 \mathrm{~L} \mathrm{ha}^{-1}$ \\
Glyphosate + Dicamba & & $0.625 \mathrm{~L} \mathrm{ha}^{-1}+0.25 \mathrm{~L} \mathrm{ha}^{-1}$ \\
\hline
\end{tabular}

*Glyphosate - Roundup Original ${ }^{\circledR}$ SL

**2,4-D - DMA ${ }^{\circledR} 806 \mathrm{BR}$

A system consisting of a reservoir with a $25 \mathrm{~L}$ capacity, positive displacement piston pump with a flow rate of $35 \mathrm{~L} \mathrm{~min}^{-1}$ driven by an electric motor of $2.24 \mathrm{~kW}$, hydraulic control with pressure regulator and gauge located on the spray control was used for spraying.

A spray boom was installed in the inner part of the wind tunnel at a horizontal distance of $2.00 \mathrm{~m}$ from the tunnel diffuser hive baffle blades and at a vertical distance of $0.50 \mathrm{~m}$ from the tunnel floor, consisting of two nozzles spaced every $0.50 \mathrm{~m}$, with spray tips, anti-drip valves, thread-type cover, sealing rings, and mesh filters 80 .

Samples were collected at distances of 5, 10, and 15 $\mathrm{m}$ in relation to the spray boom and at heights of $0.30,0.50$, $0.70,0.90$, and $1.10 \mathrm{~m}$ in relation to the tunnel floor. Collectors made of polyethylene wires of $2 \mathrm{~mm}$ in diameter and $38.5 \mathrm{~cm}$ in length were used. The sum of drift of the vertical wires $(0.3,0.5,0.7,0.9$, and $1.1 \mathrm{~m})$ was obtained for each horizontal distance of 5,10, and $15 \mathrm{~m}$ for a better understanding of the drift in terms of distance of droplet displacement of the spray tip.

The wires were fixed in a metallic support and positioned transversely to the tunnel airflow direction in the respective distances and heights mentioned. Supports were placed in vertical drawers that move on rails, facilitating the exchange of wires and so that when closed, they laterally sealed the collection points, keeping the airflow constant along the tunnel.

The experiments were carried out with a wind velocity of $2 \mathrm{~m} \mathrm{~s}^{-1}$, being measured before the application of each treatment inside the tunnel wind by means of a Minipa MDA 11 fan type digital anemometer fixed at a horizontal distance of $5 \mathrm{~m}$. Temperature and relative air humidity readings were also carried out at the same point where the anemometer was installed by means of an ICEL HT-208 digital thermohygrometer.

Each replication was sprayed for 2 minutes and during the experiment, the relative air humidity ranged from 56 to $59 \%$ and the temperature ranged from 28.7 to $28.9^{\circ} \mathrm{C}$.

The collected wires were individually stored in 0.5 $\mathrm{m}$ long PVC tubes with caps numbered according to the horizontal and vertical distance of each treatment collection. Then, $25 \mathrm{~mL}$ of distilled water was added to each tube and shaken by hand, inverting them $180^{\circ}$ for 15 times.

After this procedure, the washing water from each tube was conditioned in pots with caps identified with the same numbering of the PVC tube caps and submitted to absorbance reading using a FEMTO $600 \mathrm{~S}$ spectrophotometer, adjusted for a wavelength of $630 \mathrm{~nm}$.

For the conversion of absorbance values from each reading into marker concentration $\left(\mathrm{mg} \mathrm{L}^{-1}\right)$, a standard curve was constructed with a sample of spray solution from each treatment used and known concentrations by the sequential dilution of samples. The dye present in each sample from the collector wires was quantified with the absorbance values of each concentration and a standard curve of each treatment.

The spray solution volume $(\mu \mathrm{L})$ collected in each wire was determined from the amount of marker and water volume used for extraction in the wire washing, being the value divided by the wire area $\left(24,178 \mathrm{~cm}^{2}\right)$ to obtain the drift in $\mu \mathrm{L} \mathrm{cm}^{-2}$.

\section{Experiment II - Injury due to herbicides in cotton plants}

Experiment II used the same wind tunnel of Experiment I, as well as the treatments and design for the evaluation of injury due to herbicides in the cotton crop.

A total of 130 plastic pots with a $1 \mathrm{dm}^{3}$ capacity, 10 of them as controls, were used for the visual evaluation of the injury. Thus, two pots were used per drawer of the wind tunnel, totaling six pots per replication. The soil used was an Oxisol (Latossolo Vermelho eutroférrico típico, Brazilian Soil Classification System).

Three seeds of the cotton cultivar FM 954 GLT were manually sown per pot at a depth of $3 \mathrm{~cm}$. These seeds were treated with the fungicide/insecticide pyraclostrobin + methyl thiophanate + fipronil at the recommended dose. Thinning was carried out seven days after emergence in order to maintain one plant per pot.

Spray solution application was performed 52 days after sowing, during the vegetative stage V4. The injury caused by the herbicide drift was evaluated in two cotton plants positioned within the wind tunnel at distances of 5, 10 , and 15 meters from the spray boom at a height of 0.30 
$\mathrm{m}$ in relation to the tunnel floor, totaling six pots per replication.

These pots were placed on the metal supports of collectors of the wind tunnel, being driven transversely to the tunnel airflow direction, moved like drawers, and allowing the placement and removal of the pots without the need of entering the tunnel.

During the experiment, the relative air humidity and temperature ranged from 56 to $59 \%$ and 28.7 to $28.9{ }^{\circ} \mathrm{C}$, respectively.

After spraying in the tunnel, the pots were taken to a nursery where, at 3, 7, and 15 days after application (DAA), visual evaluations of injury of cotton plants were carried out according to the Brazilian Society of Weed Science (SBCPD, 1995).

In both experiments, the data were analyzed by descriptive statistics to analyze the measures of central tendency, dispersion, and verification of the presence of outliers. After the exploratory analysis, normality and homoscedasticity tests were performed by Shapiro-Wilk and Bartlett, respectively, followed by analyses of variance. The experiments were conducted in a completely randomized design and the treatments were arranged in a split-plot design, with plots consisting of spray solutions and subplots consisting of collection distances. In the analysis of injury, the average of two plants was considered for each horizontal distance. The drift data represented by the interaction between collection distances and spray solutions were transformed according to the method proposed by Box-Cox. The means of drift and injury were compared by the Tukey's test at 5\% significance.

\section{RESULTS AND DISCUSSION}

A significant interaction was observed between the spray solution of herbicides and horizontal distances (Table 2). This evidences a dependence of the occurrence of drift as a function of these factors, thus being performed the slicing of the interactions.

TABLE 2. Analysis of variance (ANOVA) of the collected drift of the factors herbicide spray solutions of and horizontal distances.

\begin{tabular}{lccccc}
\hline Factor & DF & SS & MS & F & p-value \\
\hline Spray solution (plot) & 4.00 & 2.40 & 0.60 & $23.28^{*}$ & $\mathrm{p}<0.05$ \\
\hline CV $(\%)$ & & & 12.72 & & $\mathrm{p}<0.05$ \\
Distance (subplot) & 2.00 & 4.59 & 2.29 & $484.07^{*}$ & $\mathrm{p}<0.05$ \\
Spray solution*distance & 8.00 & 0.65 & 0.08 & $17.25^{*}$ & \\
CV $(\%)$ & & & 5.45 & & \\
\hline
\end{tabular}

CV: coefficient of variation; DF: degree of freedom; SS: sum of squares; MS: mean square; F: F-test. *Significant by the F-test ( $p<0.05)$. (Figure 1).

The average drift results as a function of horizontal distances indicate differences in relation to the sprayed solution

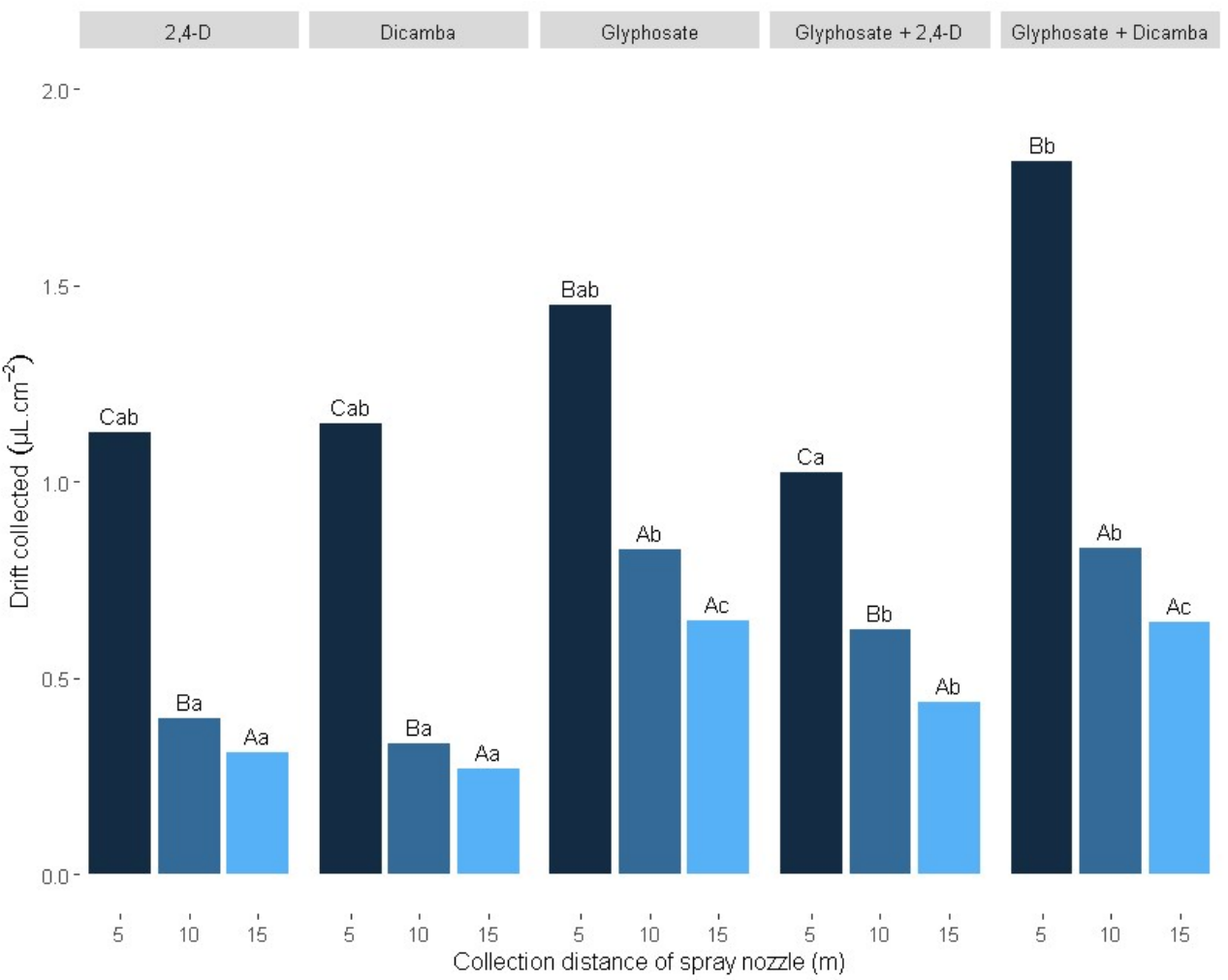

FIGURE 1. Interaction of the collected $\operatorname{drift}\left(\mu \mathrm{L} \mathrm{cm}^{-2}\right)$ as a function of collection distances of the spray tip (m) and sprayed herbicide solutions. Means followed by the same uppercase letter between the collection distances of the spray tip within each spray solution do not differ from each other by the Tukey's test $(\mathrm{p}<0.05)$. Means followed by the same lowercase letters between spray solutions do not differ from each other by the Tukey's test $(\mathrm{p}<0.05)$. The means used to construct the Tukey's test were derived from the transformation of the data by the reciprocal of the square $\operatorname{root}(1 / \sqrt{\mathrm{y}})$. 
Regardless of the sprayed solution, the drift potential in the distance of $5 \mathrm{~m}$ was higher than the other horizontal distances. The higher the distance in relation to the spray tip, the lower the collected drift, except for the spray solutions composed of the mixture of glyphosate + dicamba and glyphosate applied in isolation, which presented equal means for the horizontal distances of 10 and $15 \mathrm{~m}$. At the distances of 5 and $15 \mathrm{~m}$, the spray solution containing the mixture glyphosate + dicamba had the highest collected drift when compared to the mixture of glyphosate + 2,4-D.

When comparing the drift collected with the spray solutions composed of glyphosate and 2,4-D applied in isolation, the former showed the highest potential at distances of 10 and $15 \mathrm{~m}$. This effect characterizes the glyphosate as a higher drift potentiator when compared to 2,4-D and its application should receive special attention in this regard.

At horizontal distances of $10 \mathrm{~m}$ and $15 \mathrm{~m}$, dicamba and 2,4-D applied in isolation had the lowest potential of collected drift among all the evaluated spray solutions. The herbicide mixture potentiated the collected drift since the presence of glyphosate in the spray solutions with 2,4-D and dicamba increased significantly the drift.

Alves et al. (2017) observed a similar behavior when using the air induction turbo flat-fan spray nozzle model TTI. Gandolfo et al. (2012) found similar results with an increase of the absolute values of the collected drift with the addition of glyphosate of isopropylamine at distances of 10 and $15 \mathrm{~m}$. This effect may characterize glyphosate as a drift potentiating agent in the mixture with these herbicides.

Considering that drift can generate damages at distances higher those evaluated in this study, spray solutions containing dicamba and 2,4-D in isolation can be considered the safest among all of them when the analysis is performed on the drift potential.

A significant interaction was observed between the injury caused by drift of herbicide spray solutions and horizontal distances (Table 3). This occurred for all injury evaluation periods ( 3,7 , and 15 DAA), identified by the Ftest at $5 \%$ probability. This effect suggests a dependence of injury as a function of the horizontal distance and spray solution, but the effect of injury level provided by the different spray solutions was not evaluated.

TABLE 3. Analysis of variance (ANOVA) of drift of the factors herbicide spray solutions and horizontal distances at 3, 7, and 15 DAA.

\begin{tabular}{|c|c|c|c|c|c|c|}
\hline \multirow{3}{*}{ Factor } & \multicolumn{6}{|c|}{ DAYS AFTER EVALUATION } \\
\hline & \multicolumn{2}{|c|}{$3 \mathrm{DAA}$} & \multicolumn{2}{|c|}{$7 \mathrm{DAA}$} & \multicolumn{2}{|c|}{$15 \mathrm{DAA}$} \\
\hline & $\mathrm{F}$ & $\mathrm{p}$-value & $\mathrm{F}$ & $\mathrm{p}$-value & $\mathrm{F}$ & $\mathrm{p}$-value \\
\hline$\underline{\text { Spray solution (plot) }}$ & $22.95^{*}$ & $\mathrm{p}<0.05$ & $16.73 *$ & $\mathrm{p}<0.05$ & $33.55^{*}$ & $\mathrm{p}<0.05$ \\
\hline$\underline{\mathrm{CV}}(\%)$ & \multicolumn{2}{|c|}{11.55} & \multicolumn{2}{|c|}{14.56} & \multicolumn{2}{|c|}{11.04} \\
\hline Distance (subplot) & $178.88 *$ & $\mathrm{p}<0.05$ & $733.26^{*}$ & $\mathrm{p}<0.05$ & $804.82 *$ & $\mathrm{p}<0.05$ \\
\hline$\underline{\text { Spray solution*Distance }}$ & $4.17 *$ & $\mathrm{p}<0.05$ & $2.25 *$ & $\mathrm{p}<0.05$ & $3.60 *$ & $\mathrm{p}<0.05$ \\
\hline $\mathrm{CV}(\%)$ & \multicolumn{2}{|c|}{19.14} & \multicolumn{2}{|c|}{9.07} & \multicolumn{2}{|c|}{8.92} \\
\hline
\end{tabular}

$\mathrm{CV}$ : coefficient of variation; F: F-test. *Significant by the F-test $(\mathrm{p}<0.05)$.

The results of injury in cotton plants at 3 DAA for the different spray solutions as a function of distances are shown in Figure 2.

The herbicide glyphosate in isolation did not cause injury to cotton plants at any of the horizontal distances since the used cultivar confers tolerance to it. Thus, its injury data were not considered in the statistical analysis in order to meet the assumptions of the analysis of variance.

According to the injury observed to quantify the magnitude of damage resulting from the drift and injury of the herbicide spray solution in cotton plants at 3 DAA, the percentage of injury was higher than $30 \%$ for all the spray solution when evaluated at a horizontal distance of $5 \mathrm{~m}$ (Figure 2).

In the evaluation carried out at a distance of $5 \mathrm{~m}$ from the spray boom, the spray solution composed of glyphosate + dicamba presented the highest injury in the plants. In addition, regardless of the sprayed solution, the percentage of injury at $5 \mathrm{~m}$ was higher than the other horizontal distances, suggesting a reduction in the risk of drift at higher distances. 


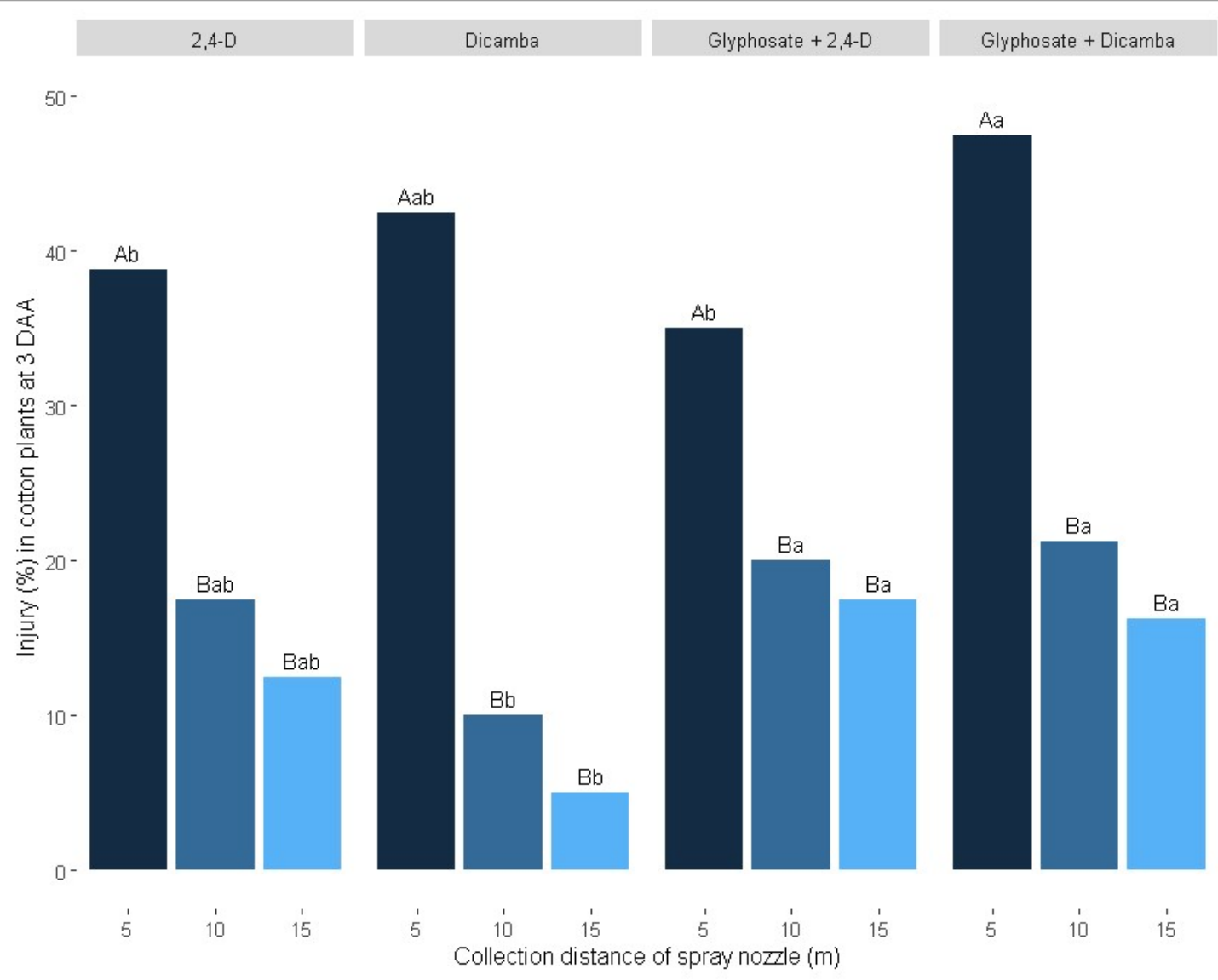

FIGURE 2. Injury (\%) in cotton plants at 3 DAA as a function of the collected drift in a wind tunnel at different distances from the spray tip $(\mathrm{m})$. Means followed by the same uppercase letter between the collection distances of the spray tip within each spray solution do not differ from each other by the Tukey's test $(\mathrm{p}<0.05)$. Means followed by the same lowercase letters do not differ from each other by the Tukey's test $(\mathrm{p}<0.05)$.

In the evaluations of 10 and $15 \mathrm{~m}$, the presence of glyphosate in the spray solution of the mixture with the herbicide dicamba increased the observed injury. These results may be related to the amount of drift and the injury potential caused by the different spray solutions.

Although the used plants were tolerant to the herbicide glyphosate, its addition to the herbicide dicamba potentiated the crop injury. Some researchers have reported similar effects on weeds, such as Spaunhorst \& Bradley (2013), who observed that the addition of glyphosate to dicamba indicates a higher control of carelessweed
(Amaranthus palmeri) plants resistant to glyphosate. The same was observed for Conyza spp., in which the association of glyphosate and dicamba considerably increases control levels (Soares et al., 2012).

In studies with plants of Convolvulus arvensis, Flint \& Barrett (1989) reported that this synergism may have occurred due to a higher accumulation of herbicides in the root region. In addition, the synergistic interaction can be explained by an increase in absorption and translocation of dicamba when in mixture with glyphosate. 


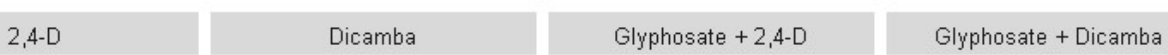

$80^{-}$

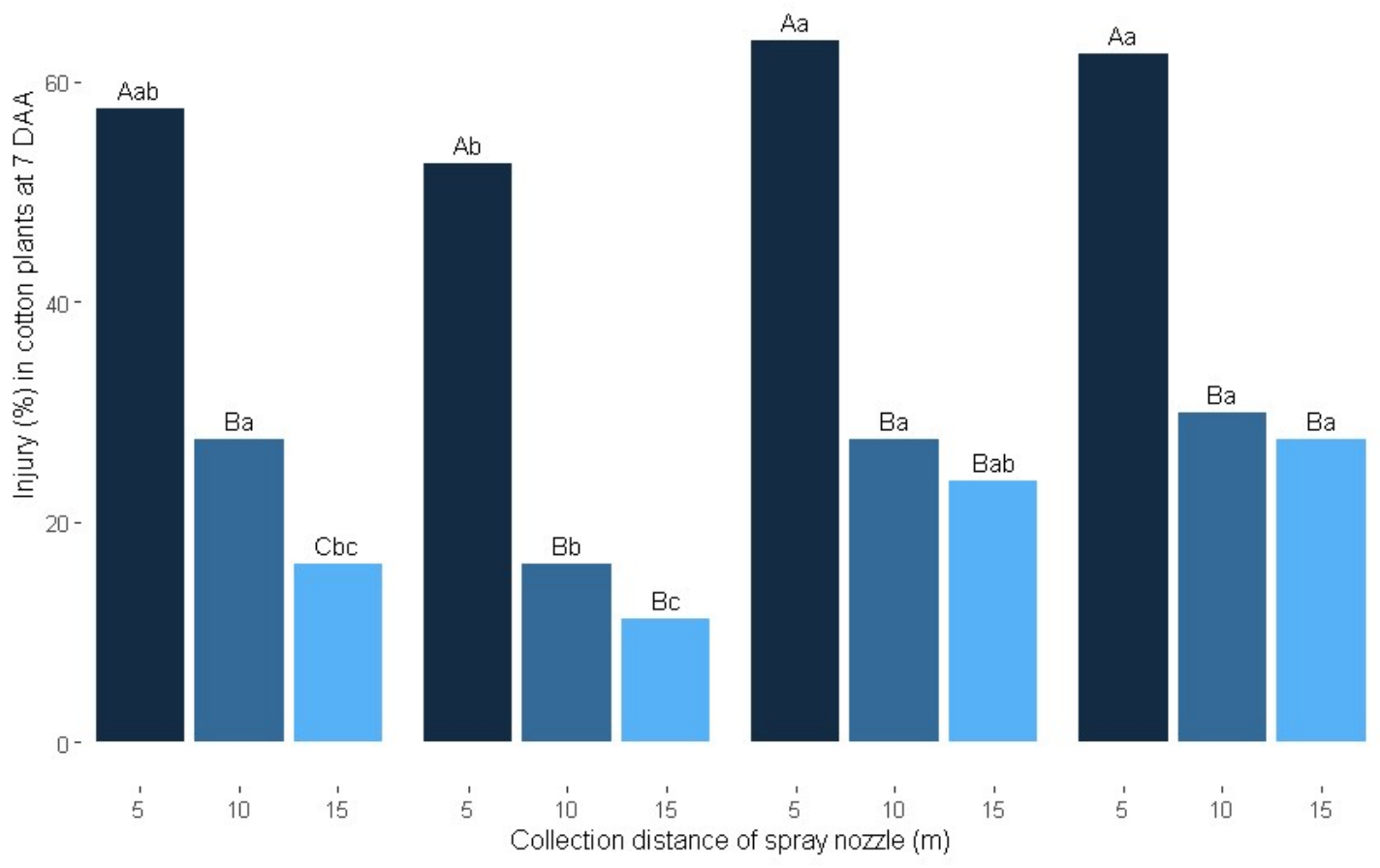

FIGURE 3. Injury (\%) in cotton plants at 7 DAA as a function of the collected drift in a wind tunnel at different distances from the spray tip (m). Means followed by the same uppercase letter between the collection distances of the spray tip within each spray solution do not differ from each other by the Tukey's test $(\mathrm{p}<0.05)$. Means followed by the same lowercase letters do not differ from each other by the Tukey's test $(p<0.05)$.

The analysis performed at 7 DAA showed that the presence of glyphosate in the spray solution in mixture with the herbicide dicamba increased the injury observed in cotton plants when compared to the herbicide dicamba applied in isolation, regardless of the distance of the spray boom.

Soares et al. (2012) observed that even in resistant plants, the addition of glyphosate may cause an additive or synergistic effect on the control. Byker et al. (2013) also reported a synergism in mixtures between dicamba + glyphosate for dicotyledonous species.

The herbicide glyphosate contains in its formulation surfactants, which alter its characteristics, assisting the contact and spreading of droplets, which determines its availability to permeate the cuticle of plants (Wagner et al., 2003). These surfactants may increase the absorption of synthetic auxins when applied in mixture, providing synergism in eudicotyledons (Peterson et al., 2016).

The injury caused by the spray solution containing 2,4-D in isolation was higher than that observed in the spray solution containing dicamba in isolation at a horizontal distance of $10 \mathrm{~m}$. A similar result was observed by Egan et al. (2014), who demonstrated that 2,4-D injuries in cotton plants were higher when compared to those of dicamba when evaluated at 7 DAA. Johnson et al. (2012) and Smith et al. (2017) evaluated the response of cotton to simulated drift of 2,4-D and dicamba and observed that the drift of 2,4$\mathrm{D}$ caused a higher injury and decreased productivity when compared to dicamba.

Although the used herbicides present the same mechanism of action (synthetic auxins), the chemical groups phenoxycarboxylic acid (2,4-D) and benzoic acid (dicamba) show differences in the control spectrum, which may explain the higher sensitivity of cotton plants to 2,4-D (Grossmann, 2010). Thus, this difference in sensitivity may also be due to the variation in the rate of metabolization of the herbicides. The spray solutions in mixtures with glyphosate did not present difference from each other regardless of the evaluated distance.

At 15 DAA (Figure 4), the injury in cotton plants caused by drift of the herbicide dicamba in isolation was lower than that observed in the evaluated spray solutions under mixture for all distances. At a distance of $5 \mathrm{~m}$, the mixture of glyphosate $+2,4-\mathrm{D}$ presented a higher injury level. Takano et al. (2013) found that the addition of glyphosate to 2,4-D increases the control levels and can accelerate the death of weeds. 
$2,4-D$

$2,4-\mathrm{D}$ Dicamba
Glyphosate + Dicamba

$80-$

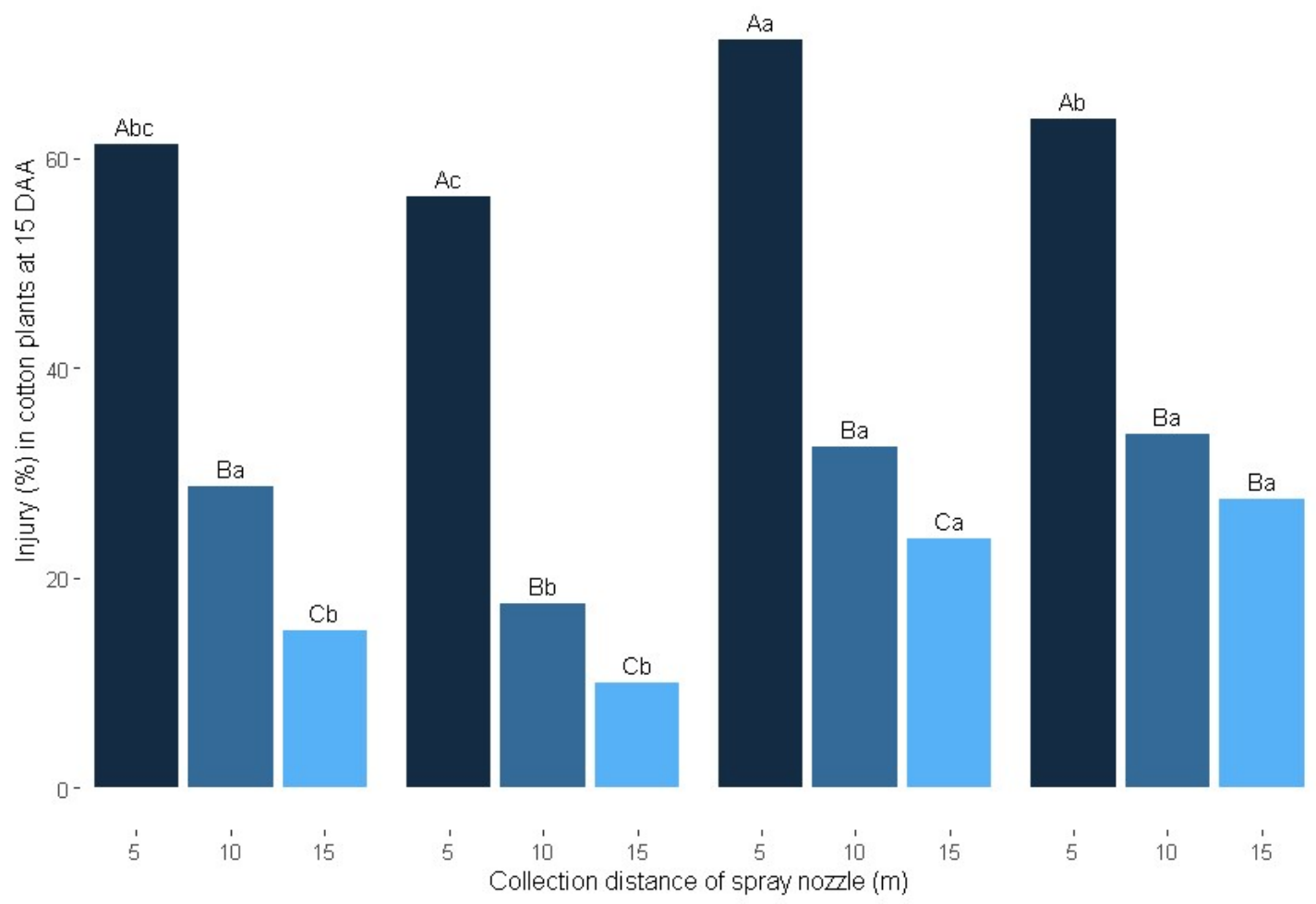

FIGURE 4. Injury (\%) in cotton plants at 15 DAA as a function of the collected drift in a wind tunnel at different distances from the spray tip (m). Means followed by the same uppercase letter between the collection distances of the spray tip within each spray solution do not differ from each other by the Tukey's test $(\mathrm{p}<0.05)$. Means followed by the same lowercase letters do not differ from each other by the Tukey's test $(\mathrm{p}<0.05)$.

At a distance of $15 \mathrm{~m}$, dicamba associated with glyphosate showed a higher injury level, which was equivalent to the mixture of glyphosate $+2,4-\mathrm{D}$. The injury caused in cotton plants indicates a leaf damage caused by the herbicide drift, leading to petiole epinasty regardless of the spray solution composition and purplishness of leaves and stems when spray solutions composed of 2,4-D is applied, besides a symptom known as frog-leg in young leaves after the occurrence of drift in the wind tunnel. The damage caused by the drift of spray solutions composed of dicamba were similar to those of 2,4-D, but some plants presented chlorosis in the leaf area. Herbicides of the group of synthetic auxins cause cellular disorganization of mesophylls, such as shape change and cell wall disturbances (Pazmiño et al., 2011), which explains the observed symptoms.

This study considered the injury in cotton plants by different herbicides and their different combinations, relating it to the percentage of drift generated by spray solutions, not evaluating the difference of injury caused by the difference of sensitivity of the crop in the manifestation of injury by the different herbicides.

\section{CONCLUSIONS}

The addition of glyphosate to the herbicides dicamba and 2,4-D potentiates the collected drift from $5 \mathrm{~m}$. At horizontal distances of 10 and $15 \mathrm{~m}$, the spray solutions composed of dicamba and 2,4-D in isolation presented the lowest collected drift potential.
At $5 \mathrm{~m}$, the percentage of injury is higher when compared to the other distances of the spray boom, regardless of the sprayed solution.

At $10 \mathrm{~m}$, the herbicide 2,4-D in isolation presented a higher injury when compared to dicamba in isolation at 7 and 15 DAA. At 10 and $15 \mathrm{~m}$, the addition of glyphosate to the herbicide dicamba potentiates the injury in cotton plants and the mixtures of herbicides do not differ from each other in relation to injury.

\section{REFERENCES}

Alves GS, Kruger GR, Cunha JPAR, Vieira BC, Henry RS, Obradovic A, Grujic M (2017) Spray drift from dicamba and glyphosate applications in a wind tunnel. Weed Technology 31(3):387-395. DOI: https://doi.org/10.1017/wet.2017.15

Byker HP, Soltani N, Robinson DE, Tardif FJ, Lawton MB, Sikkema PH (2013) Control of glyphosate-resistant horseweed (Conyza canadensis) with dicamba applied preplant and postemergence in dicamba-resistant soybean. Weed Technology 27(3):492-496. DOI: https://doi.org/10.1614/WT-D-13-00023.1

CTNBio - Comissão Técnica Nacional de Biosegurança (2016) Deliberações 198 Plenária - Dezembro. CTNBio.

Egan JF, Barlow KM, Mortensen DA (2014) A metaanalysis on the effects of 2,4-d and dicamba drift on soybean and cotton. Weed Science 62(1):193-206. DOI: https://doi.org/10.1614/WS-D-13-00025.1 
Flint JL, Barrett M (1989) Effects of glyphosate combinations with 2,4-D or dicamba on field bindweed (Convolvulus arvensis). Weed Science 37(1):12-18. DOI: https://doi.org/10.1017/S0043174500055776

Gandolfo MA, Chechetto RG, Carvalho FK, Gandolfo UD, Moraes ED (2013) Influência de pontas de pulverização e adjuvantes na deriva em caldas com glyphosate. Revista Ciência Agronômica 44(3):474-480.

Gandolfo MA, Rodrigues EB, Osipe R, Moraes ED, Gandolfo UD, Osipe JB (2012) Potencial de deriva da mistura de 2,4-D com glyphosate. Revista Brasileira de Herbicidas 11(3):332-338. DOI:

https://doi.org/10.7824/rbh.v11i3.192

Godinho Júnior JD, Vieira LC, Pereira LOA, Ruas RAA, Faria VR, Filho AC (2017) Deriva do herbicida 2,4-d aplicado com pontas hidráulicas de jato plano tipo leque. Revista Brasileira de Ciências Agrárias 12(4):550-554. DOI: https://doi.org/10.5039/agraria.v12i4a5470

Grossmann K (2010) Auxin herbicides: current status of mechanism and mode of action. Pest Management Science 66(2): 113-120. DOI: https://doi.org/10.1002/ps.1860

Grossmann K, Scheltrup F, Kwiatkowski J, Caspar G (1996) Induction of abscisic acid is a common effect of auxin herbicides in susceptible plants. Journal of Plant Physiology 149(3-4):475-478. DOI:

https://doi.org/10.1016/S0176-1617(96)80153-2

Heap I (2014) Global perspective of herbicide-resistant weeds. Pest Management Science 70(9):1306-1315. DOI: https://doi.org/10.1002/ps.3696

Johnson VA, Fisher LR, Jordan DL, Edmisten KE, Stewart AM, York AC (2012) Cotton, peanut, and soybean response to sublethal rates of dicamba, glufosinate, and 2,4-D. Weed Technology 26(2):195-206. DOI: https://doi.org/10.1614/WT-D-11-00054.1

Minozzi GB, Monquero PA, Pereira PA (2014) Eficácia de diferentes manejos de plantas daninhas na cultura da soja transgênica. Revista Brasileira de Ciências Agrárias 9(3):406-412. DOI: http://dx.doi. org/10.5039/agraria.v9i3a4499

Mohseni-Moghadam M, Doohan D (2015) Response of bell pepper and broccoli to simulated drift rates of 2,4-d and dicamba. Weed Technology 29(2):226-232. DOI: https://doi.org/10.1614/WT-D-14-00105.1

Mortensen DA, Egan JF, Maxwell BD, Ryan MR, Smith RG (2012) Navigating a critical juncture for sustainable weed management. BioScience 62(1):75-85. DOI: https://doi.org/10.1525/bio.2012.62.1.12

Oliveira DP, Santos SMS, Lacerda JJ, Lima HA, Silva RA (2015) Alterações morfológicas na cultura do algodão provocada por subdoses de 2,4-D na fase inicial de desenvolvimento da cultura. Revista Cultivando o Saber 8(4):414-426.
Pazmiño DM, Rodríguez-Serrano M, Romero-Puertas MC, Archilla-Ruiz A, Del Rio LA, Sandalio LM (2011) Differential response of young and adult leaves to herbicide 2, 4-dichlorophenoxyacetic acid in pea plants: role of reactive oxygen species. Plant, cell \& environment 34(11):1874-1889. DOI: https://doi.org/10.1111/j.13653040.2011.02383.x

Peterson MA, Mcmaster SA, Riechers DE, Skelton J, Stahlman PW (2016) 2, 4-D past, present, and future: a review. Weed Technology 30(2):303-345. DOI: http://dx.doi.org/10.1614/WT-D-15-00131.1

SBCPD - Sociedade Brasileira da Ciência das Plantas Daninhas (1995) Procedimentos para instalação, avaliação e análise de experimentos com herbicidas. SBCPD, 42p.

Schaianne AG, Arantes SACM, Andrade EA, Arantes KR, Viana DN, Pereira JR C (2017) Residual effect of mixture of glyphosate and 2, 4-D in winter maize in diferente soil textures. Revista Brasileira de Engenharia Agrícola e Ambiental 21(5):317-321. DOI:

http://dx.doi.org/10.1590/1807-1929/agriambi.v21n5p317321

Sidahmed MM, Awadalla HH, Haidar MA (2004)

Symmetrical multi-foil shields for reducing spray drift. Biosystems Engineering 88(3):305-312. DOI: https://doi.org/10.1016/j.biosystemseng.2004.04.006

Silva AA, Vivian R, Oliveira Jr RS (2007) Herbicidas: comportamento no solo. In: Silva AA, Silva JF (eds). Tópicos em manejo de plantas daninhas. Viçosa, Universidade Federal de Viçosa, p189-248.

Smith HC, Ferrell JA, Webster TM, Fernandez JV (2017) Cotton response to simulated auxin herbicide drift using standard and ultra-low carrier volumes. Weed Technology 31(1):1-9. DOI: https://doi.org/10.1614/WT-D-16-00101.1

Soares DJ, Oliveira WS, López-Ovejero RF, Christoffoleti PJ (2012) Control of glyphosate-resistant hairy fleabane (Conyza bonariensis) with dicamba e 2,4-D. Planta Daninha 30(2):401-406. DOI: http://dx.doi.org/10.1590/S0100-83582012000200020

Spaunhorst JD, Bradley KW (2013) Influence of dicamba and dicamba plus glyphosate combinations on the control of glyphosate-resistant Waterhemp (Amaranthus rudis). Weed Technology 27(4):675-681. DOI: https://doi.org/10.1614/WT-D-13-00081.1

Takano HK, Oliveira Jr RS, Constantin J, Biffe DF, Franchini LHM, Braz GBP, Rios FA, Gheno EA, Gemelli A (2013) Efeito da adição do 2,4-D ao glyphosate para o controle de espécies de plantas daninhas de difícil controle. Revista Brasileira de Herbicidas 12(1):1-13. DOI: http://dx.doi.org/10.7824/rbh.v12i1.207

Wagner P, Fürstner R, Barthlott W, Neinhuis C (2003) Quantitative assessment to the structural basis of water repellency in natural and technical surfaces. Journal of Experimental Botany 54(385):1295-1303. DOI: https://doi.org/10.1093/jxb/erg127 